\title{
Political Ecology of the Small-scale Gold Mining in Cagayan de Oro City, Philippines
}

\author{
Catherine Roween C. Almaden \\ College of Arts and Sciences, Xavier University - Ateneo de Cagayan, \\ Corrales Avenue, Cagayan de Oro City, 9000 Philippines \\ Email Address: calmaden@xu.edu.ph
}

\section{Doi:10.5901/mjss.2015.v6n1s1p351}

\section{Abstract}

The use and exploitation of mineral resources by rural communities in a collective form is at the centre of the livelihoods in many developing countries such as the Philippines. The issues are usually concentrated on common property regimes, that is to say, the legal regime, which governs the extraction and disposal of natural resources. The study is an analysis of the political ecology of a contested common pool resource in the case of small-scale gold mining in the barangays along the Iponan River in Cagayan de Oro City Philippines. Firstly, it assessed the socio-economic conditions, described the mining activities and identified problem areas in the communities. Secondly, it discussed the actors involved, especially the miners who find mining as an important source of income and a survival strategy for impoverished people in the communities. Thirdly, it reviewed the institutions and the policies that govern the sector. Lastly, social impacts that resulted to a host of major social and environmental problems were discussed. The political ecology of the SSGM sector in the city is plagued with institutional problems. These include weak legislation, complex policies and poor implementation and sometimes government marginalization.

Keywords: Illegal Mining, Marginalization, Political Ecology, Small-scale Gold Mining

\section{Introduction}

Small-scale gold mining (SSGM) plays a crucial role in poverty alleviation and rural development in many developing countries. Most of those involved are poor and mining represents the most promising, if not the only, income opportunity available. It is estimated that 13 million people in about 80 countries are directly engaged in small-scale mining, a significant proportion of whom are women and children. The latest official figures were 80 to 100 million people across the developing world are dependent on small-scale mining for their livelihoods (ILO, 2003).

However, the sector is largely unlicensed. Governments in many countries regard it as an illegal activity. The absence of regulatory and policy framework prevent formalization of this sector. In turn, improvements in the livelihoods of miners are difficult to achieve and environmental protection problematic. In addition, the potential economic benefits of the small-scale mining sector are not realized due to unsustainable practices in mining and processing and impaired marketing channels.

As a result, SSGM are often marginalized (Carson, et al., 2005). While different definitions exist, it is often defined by the use of rudimentary extraction practices (Hinton, 2006). In the Philippines, it refers to activities which heavily rely on manual labor using simple implements and methods and do not use explosives or heavy mining equipment (RA 7076). It was estimated that the sector employs about 200,000 to 300,000 miners.

While numerous studies on mining have already been undertaken in the country to guide policymakers in alleviating the challenges in the sector, certain areas remain to be inadequately understood. The case study presented here focuses on the political ecology surrounding SSGM sector that has taken place in Cagayan de Oro City, Philippines. The SSGM activities in Cagayan de Oro were not also documented officially. According to a government official from the Mines and Geosciences Bureau of Region 10, the sector is too small and the contribution quite insignificant. Though the sector may be deemed relatively small, hydraulic mining for gold activities has been sweeping across the upstream rural barangays in Cagayan de Oro City in the past two decades. Not to mention, the environmental impacts are very much evident in the degradation of the Iponan River which extends to the Macajalar Bay. The debilitating effects of the unregulated mining activities are not only concentrated on the environment. It also encompasses the indigenous cultural communities, the health and safety of people, as well as their means of livelihood. It was within this context that the analysis on the political and the structural challenges of the SSGM sector of the city are conducted for the barangays along the Iponan River. 


\subsection{Objectives of the Study}

This study analyzed the political ecology of SSGM in Cagayan de Oro City. Specifically, it described the sociodemographic and economic characteristics of the communities, provided an overview of its operations; discussed the institutional context; identified the social impacts and the current issues and challenges.

\subsection{Related Literature}

The Political Ecology approaches are based on specific ways of inquiry rather than on a coherent theory (Bryant and Bailey, 1997). The main Political Ecology approach is to understand the phenomenology underlying environmental changes and they affect different social groups. Actors' perceptions and interests receive special attention in political ecology studies (Blaikie, 1995).

Political ecology also typically address unequal power relations regarding access to and control over resources, the reflection of such power relations in discourses and claims about the environment and development, and resistance and opposition to unequal social-environmental dynamics (Tschakert, and Singha, 2006).

A major dimension relates to the exclusion of marginalized social groups from access to and rights over mineral resources. This may involve the classification of small-scale miners as illegal due to poor availability of land, insufficient institutional support, and complicated licensing systems (Hilson and Potter, 2003), or the expansion of large-scale mining operations into regions previously occupied by small-scale miners (MMSD, 2002). Commonly, these processes are often bound together, with the government favoring large-scale mining interests, and small-scale miners put at a disadvantage position. This is demonstrated by the rapid change in rural livelihoods in Africa (Bryceson, 2002) resulting to local competition, conflict and power concentration in the institutionalization of rights and entitlements to mineral resources (Benjaminsen and Lund, 2002).

This attribute on the political ecology of the SSGM sector contribute to limited economic opportunities. Not to mention, SSGM miners usually belong to socially and economically marginalized communities, and turn to mining in order to escape extreme poverty, unemployment and landlessness (Tschakert and Singha, 2006).

More fundamentally, marginalization is a common feature of the sector. This is due to the connotations of SSGM as illegitimate activities, taking place in social and geographical arenas away from state control (De Boeck, 1999; Heemskerk, 2001). This frequently leads miners to be associated with illegality (Duffy, 2005; Hilson and Potter, 2003) and stereotyped as criminals, a common label for marginalized people in the informal economy (Tripp, 1997).

Oftentimes, SSGM as a sector has been marginalized geographically and politically. The absence of the sector in national development plans is both a cause and effect of this. To a large extent, the industry has always been viewed politically as a marginal sector not only because of its geographic remoteness but also the rudimentary nature, and the preference given by government to the higher profile large-scale mining (LSM) sector, as well as the government and public perceptions of its significance in relation to other sectors such as agriculture (Centre for Development Studies, 2004).

In many countries, national institutional and regulatory frameworks relating to the mining sector have been established largely to respond to large-scale mining, and often do not take the particularities of small-scale mining into account. Some countries that have recognized and legalized SSGM and have provided support services for operators, have seen a marked increase in mineral output and revenue. These countries include Columbia, Ghana, Guyana and the Philippines. In these countries, environmental impact assessments (EIAs) were introduced specifically aimed at smallscale miners, in an attempt to reduce the negative environmental impact of these industries (Drechsler, 2001; Espinosa Bula, 2000; Hilson, 2002). However, these are often financially and administratively prohibitive to small-scale miners and inappropriate overall (Centre for Development Studies, 2004).

\subsection{Methodology}

The study used both qualitative and quantitative methods. Secondary data were sourced from various government agencies. In most instances, the study relied heavily on primary data. Primary data collection was conducted using multiple approaches, including; household survey, focus group discussions (FGDs), interviews with key informants, and observation. Due to financial and time constraints, around 15-22 households were surveyed in each barangay. 


\section{Results}

\subsection{Physical Characteristics of the Communities}

\subsubsection{Location}

The upstream Barangay of Tumpagon is bounded by Iponan River on the north and west side, Province of Lanao on the south and Barangay Pigsag-an on the east. The midstream portion is located in the upper east side of Cagayan de Oro City, 23.5 kilometers from the center of Cagayan de Oro City, the Golden Friendship Park. It is geographically situated in the barangays of Pagalungan, Tagpangi, Taglimao, Pigsag-an, and Tignapoloan. The downstream portion of Iponan River is bounded by Barangay Pagatpat. Iponan River extends northward and empties its water in the Macajalar Bay. Hydraulic, panning and open-pit gold mining in the upstream and midstream barangays have caused siltation, erosion, sedimentation and pollution in the Iponan River as well as the Macajalar Bay.

\subsubsection{Land Use Classification}

The upstream barangays along the rivers where the hydraulic mining operation is active, is generally hilly and undulating. This is the most obvious characteristic of the area, and this topography of the landscape made farming difficult as evidenced by sparse cropping of the whole area. As stated in the Barangay Development Plan, the Barangay Officials plan to request the Department of Environment and Natural Resources for a land survey so that lands could be subdivided for economic improvement. Participants of the FGD estimate that around $30 \%$ of the barangays land area is already being mined.

Midstream barangays which include Tuburan, Pagalungan, Tagpangi, Taglimao and Tignapoloan are characterised by a hilly landscape. The barangays are generally classified as alienable and disposable lands ( $49 \%$ of the land area), 40\% are agricultural land and $10 \%$ protected forest areas. FGD members claimed that the barangay is under ancestral domain.

Ocular survey in the area revealed that hydraulic mining is in operation in many parts of the eight upstream and midstream barangays. Hydraulic mining activities are within half kilometer from riverside. Deep excavations were made, changing the natural landscape, exposing rocks and boulders from the depth of the soil. This renders many portions unfit for any gardening activity.

The whole area virtually lacks the necessary road networks making transport of farm inputs and products difficult. Most of the roads are near rivers and households only. Most of the flat areas are also found near rivers.

A small proportion of the area has been planted with crops. Majority are perennials such as coconuts, bananas, bamboos, jackfruits, and cashew. Coconuts and bananas are the most common. Most of these perennials are planted near houses and in hilly portions of the landscape. A large portion of the area is mostly filled with lush growth of weed vegetations indicating that the soil is generally fertile and can support growth of crops.

\subsection{Socio-Demographic Characteristics}

\subsubsection{Population and Household Characteristics}

Based on the 2010 Census of Population and Housing (CPH), Cagayan de Oro City, a highly urbanized city in the province of Misamis Oriental, posted a total population of 602,088 persons as of May 1, 2010. The increase in the population count from 2000 to 2010 translated to an average annual population growth rate (PGR) of 2.69 percent. As for the barangays covered in the study, the total population in the same period is 15,305 with total number of households at 3,201. The average household size of the barangays is 5.34. The details are shown in Table 1. 
Table 1: Total Population and Total Households of SSGM Barangays

\begin{tabular}{|c|c|c|}
\hline Barangay & Total Population & Total Households \\
\hline Pagalungan & 1806 & 418 \\
\hline Pigsag-an & 1256 & 214 \\
\hline Taglimao & 1418 & 308 \\
\hline Tagpangi & 2684 & 618 \\
\hline Tignapoloan & 4514 & 899 \\
\hline Tuburan & 1395 & 288 \\
\hline Tumpagon & 2232 & 476 \\
\hline Total & 15305 & 3211 \\
\hline
\end{tabular}

Source: National statistics Office, 2010 Census of Population and Housing (CPH)

Seventy percent of the households are male-headed. The age distributions of parents in these households are as follows: $50 \%$ are under age bracket 20-30; another $37 \%$ under age-category 31-40, and the rest of the $13 \%$ belonging to 51-60 age-bracket. The ages of children living with parents in the household surveyed vary from five months to twenty six years old. Seventy percent of the children are below 15 years old, denoting relatively high dependency ratio.

\subsubsection{Ethnicity}

Around $70 \%$ of the upstream and midstream barangays are composed of "Lumads" or indigenous people, specifically from the Higaonon tribe. The rest are mostly Cebuanos who migrated to the barangays from late 1990's up to the present. The downstream barangays rarely have residents belonging to the indigenous group.

Membership in the Higa-onon group has implications on their rights as indigenous people as mandated by R.A. 8371 (Indigenous Peoples Rights Act). For government officials, this means looking first and foremost into the status of the IPs' claim to their ancestral lands and consequently on the ways by which these lands could be productively managed by the IPs themselves.

\subsubsection{Education}

The survey in the upstream and midstream barangays showed that $38 \%$ of the parents in households are grade school graduates, $28 \%$ are high school graduates, and the rest are a mixed of high school and grade school levels only. Most of the children of the members of the households surveyed are of school age but majority of the children finish only elementary level.

In general, a grave concern of the barangays is the high number of out-of-school youth (OSYs). Out of school youth comprise a source of great energy, which in the case of the upstream and midstream communities are a source of labor for small scale hydraulic mining.

\subsection{Socio-Economic Characteristics of the Communities}

\subsubsection{Housing and Facilities}

Most of the $73 \%$ of residents of the midstream and upstream barangays own their house and lot by means of tax declaration. A Tax Declaration is granted by the Philippines Government in lieu of freehold land. They cannot be rescinded by the Government except in very rare cases of national interest. Tax Declarations cannot be used as loan instruments or collateral. While Tax Declarations do not provide the absolute security of indefeasible title provided by a Torrens Title, it is however, the next best thing. They are universally recognized in Philippine jurisprudence as evidence of possession (Republic Act No. 386, The Civil Code of the Philippines).

The sizes of their houses range from 20 to 60 square meters while lot sizes range from 30 to 200 square meters. Majority of the houses were partitioned into two rooms, one serving as a multi-purpose room, the other as bedroom. The FGD members reported that majority maintain two houses, one in the barangay center and the other a temporary dwelling near the river to increase access to the mining sites. Further, proximity to the river is also convenient for those who engage in agriculture. 
Financial Resources

\subsubsection{Savings}

Ninety percent of households claimed that their earnings are just enough for the household daily needs. Based on the results of the survey, only ten percent of households practice the value of savings either in direct savings (piggy bank) or through membership in a cooperative. Interestingly, members of the FGD in upstream and downstream barangays all agreed that most of the time they have a problem managing their personal finances. There was also an outpour of suggestions regarding the availability of a program that will help them improve their knowledge regarding this issue. Fifty percent of those who save keep their savings at home. Thirty percent save through the cooperative while the remaining twenty percent saves through the "huluga" system (rotational groups).

\subsubsection{Credit Access}

Results coming from both the survey and FGD in the upstream and downstream barangays showed that they normally resort to the financer of the mining activity for their financial needs. There are also sari-sari stores that grant credit for those who are known to be actively involved in mining. There is an absence of a formal sector that grants credit in the area.

\subsubsection{Sources of Livelihood}

Barangays in the upstream and midstream are known to be inhabited by "Lumads". However, recently, migrants from nearby provinces are now residing in the barangay. While the former used to live on hill tracts amidst forests and are shifting cultivator they later became plain dwellers and depended primarily on mining for their livelihood. Information from both FGD and the survey showed that mining was the primary source of livelihood in the barangay. This accounted for about $70 \%$ of all the residents. Twenty percent are engaged in farming, and $10 \%$ in small trading activities and personal services jobs. Households who are dependent on mining usually find supplementary income through farming, and the families who are engaged in farming also find supplementary income through mining.

\subsubsection{Farming}

The members of the FGD groups and the majority of respondents in the survey for the upstream and midstream barangays claimed they were involved in farming ten years ago but and have left it since then as a major source of livelihood. This is attributed to the low earnings from farming as a livelihood. The average income earned for farming is estimated to be between Php 2,000.00-3,500.00 per month.

\subsubsection{Land Tenure and cultivation}

Sixty percent of the households in the upstream and midstream barangays own farm lots ranging from 2-10 hectares. However, only $20 \%$ of the households with farm lots are actively engaged in farming at the time of the survey. Eighty percent of land ownership in these two barangays are under tax declaration statuses while only $20 \%$ of the households with land sizes between 6-10 hectares are titled.

The survey showed that farming households cultivate farms with sizes ranging from $100 \mathrm{sq}$. meters to 4 hectares. However, small farm-owners cultivate an average farm-lot measuring between 100 and 800 sq. meters.

\subsubsection{Crops}

Marginal farming of crops in the barangays cultivated areas include corn, banana, coconuts and cassava. Corn production which used to be the main economic activity at the household level, presents a number of challenges to the farmers. In itself as a practice, subsistence farming can no longer sustain the growing population needs for food. The yields realized by households are low. This is because households cannot afford inputs and improved seed varieties to increase yields. This implies that the farmer has to recycle the seeds on the same plot, which makes them more vulnerable to pests and diseases.

According to them, the income is not enough to cover for seeds and fertilizer costs. On top of that, it entails high 
transportation costs due to absence of buyer in the barangay, requiring them to transport their produce to the Cagayan de Oro City proper. Every sack transported through the jeepney would cost Php 50.00.

On the other hand, households involved in farming bananas can only recover around $50 \%$ of the potential harvest. Selling their produce also require additional transportation cost. Overall, large scale commercial crop production in these barangays has become uncommon at present because of the challenges it poses.

Only few in the two barangays maintain home garden cultivations which are dominated by cassava, sweet potato and coconut. Ninety percent of these crops are utilized for household consumption and only ten percent for commercial purposes. Both the FGD and survey revealed that the agriculture yields cannot sustain the basic food requirement of the people and their domestic animals.

\subsubsection{Livestock}

On the average, around $40 \%$ of households in the barangays own livestock. Information gathered from FGD and the surveys showed that the common animals reared by the households are chickens, goats and pigs. The domestication of these animals is purely for home consumption. Households that own carabaos, horses and cows are commonly engaged in farming activities. The rarity of livestock production among the households in the barangay is attributed to lack of finances for the animal food and medicine needs. Also, livestock in the area is prone to cholera attacks and other related diseases.

\subsection{Small-scale Gold Mining}

\subsubsection{Earliest Accounts on Mining Activities}

According to the FGD members, mining in the upstream barangays started in the late 1970s. It peaked in the mid-1980s when, flushing and wide scale digging were intensified with the use of large pipes, gas pumps and machines.

In the midstream barangays, reports both from the FGD and the survey cited that the earliest mining activity can be traced way back in 1982. This was initiated by a foreigner who used to engage in small scale farming (allegedly, a bee farm) in the area. Shortly thereafter, this foreigner started excavation activities with the aid of a machine. Unconfirmed stories claim that the foreigner left after three years of excavation activities after discovering a huge amount of gold which encouraged the "Lumads" in the area to actively engage in small scale mining activities. Mining activities during that period consist of manual excavation and panning near the river bank. Flushing in the mountains and hills started in the late 1990s when they started employing machines to speed up their activities.

\subsubsection{Nature of its Operation}

Gold mining in the upstream and midstream barangays is predominantly a small scale activity. Production is organized as a joint venture consisting of ten to twenty people per gold pit. Each individual member is entrusted with a specific function to perform and shares of output are accorded depending on the value (monetary) and the importance of the service rendered. The flushing or excavation activity normally starts at 5 am and ends at $4 \mathrm{pm}$. It is done daily except on Sundays.

Hydraulic mining involves flushing of water to the hills/river banks, irrigating the mud to the river through the screens to filter gold. Other miners will pan called "biling" in the river to further obtain gold. The miners look for a reddish stone which they call as "tawasi" in choosing a site to mine. They believe that the "tawasi is a good indicator for gold.

Most of the manual job, i.e. digging, excavating, hauling, picking and transporting or providing security are assigned to the male laborers while women and children ages seven and up are assigned to the washing, clearing, segregating the rocks from the hauled dirt and sorting waste. The nature of its operation shows considerable diversity in scale and in employment. Each role tends to have its own local incentives and accountability structures. They are hired by a gang leader who is usually the owner of the equipment, or pit and shoulders all the costs and sets the terms of employment.

Tools and equipment used in the mining process were rudimentary in nature and required muscle power. The common mining tools used in a team of ten miners include a gas pump, at least 20 meters of hose, shovels, panning basins, ropes, sand strainers and candles. The bulk of the fixed expenses come from the acquisition of the gas pump that normally cost Php7,500.00 and the water hose. It is estimated that these equipment last up to three to five years.

The gross sales is divided by $20-80$ sharing scheme. The twenty percent $(20 \%)$ is given to the owner of the land 
while the eighty percent $(80 \%)$ is appropriated to the gang leader and the laborers. The determination of the net income is based on a proportional sharing scheme. The gang leader is provisioned with a three-person share, thus the laborers get two shares from the net income.

On a monthly basis, a mining team of 20 people can clear up to $1 / 4$ hectare of a field, dig six meters deep and create a 20 meter long tunnel. This monthly activity requires on the average, two gas pumps, at least fifty meters of water hose and six drums of gasoline. This can generate on the average 400 grams gold worth five hundred twenty thousand pesos (Php 520,000.00) pegged at the price of gold equivalent to one thousand three hundred pesos (Php 1,300.00) per gram.

FGD members and respondents of the surveys identified at least three major buyers of gold in each barangay. Occasionally, a buyer from Cagayan de Oro city would also visit the area. Also, there are those who sell their gold in Cagayan de Oro City, somewhere in Cogon Market to generate higher earnings because gold is bought at a higher price.

Based on this monthly gross income, a land owner earns an average income equivalent to Php 104,000.00, while a gas pump \& hose owner earns Php 213,168.00, the largest earner in the team. On the other hand, an ordinary laborer earns a monthly income of Php 7,105.60 or approximately Php 300.00 on a daily basis. Table 2 shows the financial details of the monthly activity.

Table 2: Estimate of Mining Financial Outlay

\begin{tabular}{|c|c|c|}
\hline Appropriation & Computation & Amount \\
\hline Land Cost (LC) & $\begin{array}{l}\text { Land Owner } \\
(20 \% \text { of the total Revenue) } \\
=\text { Php } 520,000.00 \times .20\end{array}$ & Php 104,000.00 \\
\hline Operational Cost (OC) & $\begin{array}{l}6 \text { drums of gasoline } \\
\text { (220 liters in } 1 \text { drum at Php 46.00/liter) }\end{array}$ & Php 60,720 \\
\hline Total Revenue (TR) & $\begin{array}{l}400 \text { grams of gold } \\
\text { at } 1,300 \text { pesos per gram }\end{array}$ & Php 520, 000 pesos \\
\hline Net Revenue (NR) & $\begin{array}{l}T R-(L C+O C)=N R \\
520,000.00 \\
\text { minus } 104,000.00 \\
\text { minus } 60,720.00\end{array}$ & Php 355, 280.00 \\
\hline & $\begin{array}{l}\text { Gang Leader } \\
(60 \% \text { of net revenue) } \\
=\text { Php } 355,280.00 \times .60 \\
\end{array}$ & Php 213,168.00 \\
\hline Net Revenue Sharing & $\begin{array}{l}20 \text { laborers } \\
(40 \% \text { of net revenue) } \\
=\text { Php } 142,112 \div 20 \\
=\text { Php } 7,105.60 \div 24 \text { days }\end{array}$ & $\begin{array}{l}\text { Monthly Earnings: } \\
\text { Php 7, 105.60/ laborer } \\
\text { Daily earnings } \\
\text { Php 296.06/laborer }\end{array}$ \\
\hline
\end{tabular}

\subsubsection{Mining as a Form of Livelihood: The Benefits Perceived by the Miners}

A livelihood is the means, activities, entitlements and assets by which people make a living, which is immediate and continuous. It is also a framework that seeks to build the capacity of people to continuously make a living and improve their quality of life without jeopardizing the livelihood option of others, either now or in the future by coping and adaptive strategies (Aubynn, 2004; Labonne and Gilman, 1999).

Rural people usually determine their livelihood by their ability to satisfy the basic needs of the household. Traditionally, rural people in upstream and midstream barangays made their living from agriculture. Mining was seen as a means to supplement household income following the end of the agricultural season, but as mining activities around that area became widespread in the mid-1980s, it became the main source of income, attracting not only locals but also individuals from other regions. These people are driven to mine because of poor crop harvests, expensive farming inputs and inaccessible and poor markets for their produce due to very high transportation cost and low prices for their products. Occasionally, they also experience farming problems due to unfavorable weather conditions.

Presently, around $80 \%$ of residents in the midstream and upstream barangays are actively engaged in mining. These people see mining as the most favorable livehood in the area because it gives them immediate allowance for their daily sustenance. An individual on the average earns Php 200.00-300.00 daily. Thus, if there are two or more members active in mining, their combined daily income would be sufficient to provide for the needs of a household. 
No special skills are required to engage in mining which allows active participation of both women and children. A distinct advantage of having female members of the household involved in mining is that they are more likely than men to spend their incomes on maintaining their families - investing in, for example, food, schooling, clothing, or agriculture. Men are more likely to spend their wages on gambling, alcohol, and other vices.

Mining also allowed them to continuously have a source of daily income because the cost of engaging of a mine laborer is minimal. Also, the cost of acquiring a gas pump is about 7,500 pesos at which recovery takes a month or less. On the other hand, the market for gold is very accessible and lucrative. They can easily sell the gold within the barangay which eliminates transportation cost.

Those who were actively involved in mining were open in pronouncing that mining has not only secured their food needs but also enabled them to send their children to school, some even up to college and allowed them to buy appliances and construct relatively bigger and sturdier houses.

As stated, varying weather conditions do not pose a problem for mining activities. During wet season, they intensify flushing activities in the mountains and during dry season, they transfer their dig sites near the river banks.

\subsubsection{Livelihood Vulnerability of the SSGM in Cagayan de Oro City}

SSGM in Cagayan de City is widely marginalized. SSGM miners belong to socially and economically marginalized communities, and turned to mining in order to escape extreme poverty. The mining activities in the barangays can be attributed to several economic constraints. Key findings from the barangays indicate that people turned to mining because agricultural livelihood are constrained by seasonality of activities, limitations on land tenure and land size, and limited access to capital, water supply, and access to markets.

However, dependence on mining puts people on a high level of vulnerability. Vulnerability is situation that influences the ability of people to anticipate and overcome shocks and hazards (Wisner 2004). People are vulnerable when they have limited ability to overcome unpredictable crises and shocks such as calamities, sickness, environmental degradation and worsening, terms of trade, etc. (DFID, 2000). Poor people are especially vulnerable, as they have few buffers or resources to cope with hazards or shocks (IDS 2012).

Mining activity is highly prospective. The chances of success are generally slim. The major problem for small-scale gold mining is the lack of financial resource to buy modern equipment for prospecting and excavation. The miners become highly dependent on the middle men to finance the excavation or villagers join forces to set seed money. The illegal nature of mining also serves as a serious impediment to improving the livelihood.

Consequently, the level of vulnerability of the community is high. The community is vulnerable to shocks that may come about from a number of ways. This context of vulnerability places the community into a cycle of dependence, not only upon the seasons and but largely on mining activities and also on government, private land owners and business people, who are potentially able to take advantage of the community's position of vulnerability and to exploit them.

\subsection{Institutional Context}

\subsubsection{Policy Environment}

There are two laws that primarily govern small-scale mining in the Philippines. These are Presidential Decree (PD) 1899, "Establishing Small-Scale Mining as a New Dimension in Mineral Resources Development, issued in 1984 by President Ferdinand Marcos and RA 7076, "People's Small-Scale Mining Act of 1991, enacted during President Corazon Aquino Administration.

Mines and Geosciences Bureau (MGB), one of the regulatory agencies, reported that monitoring and regulating SSGM activities is difficult at present since there is confusion over which of RA 7076 or PD 1899 truly governs smallscale mining. The Department of Justice (DOJ) issued Opinion No. 29, Series of 2011 to clear this problem. It stated that RA 7076 completely repealed PD 1899.

RA 7076 requires all small-scale miner or processor to obtain a license approved by the Department of Environment and Natural Resources (DENR) Secretary or his duly authorized representative. The license shall be valid for two (2) years and renewable every two (2) years. The miners will only be allowed to mine in the areas identified by DENR as "People's Small-Scale Mining Areas" or "Minahang Bayan." In addition, all gold produced by small-scale miners shall be sold to the Bangko Sentral ng Pilipinas (BSP), the central bank of the country or its duly authorized representatives. Fifteen percent of the government revenue share shall be allocated for the establishment of People's Small-Scale Mining Protection Fund. It also requires the formation of Provincial/City Mining Regulatory Board to regulate 
small-scale mining activities.

Almost two decades have passed since the enactment of People's Small-scale Mining Area but the legal requirement for LGUs to establish central processing zones for SSGM activities has not yet been complied. In essence, this has also contributed to ASM into an illicit activity. This may stem from the fact that most mining policies and related regulations in the country are silent on such activity and implementation focused only on large scale or formal mining sector. The existing policies for small-scale mining proved to be inadequate and structures of governance are weak, as outlined by National Strategic Plan for the Phaseout of Mercury in Artisanal and Small-Scale Gold Mining in the Philippines, 2011.

According to the miners and the barangay officials, the provisions of RA 7076 is not yet implemented in the barangays. This resulted to conflicts and socio-economic problems on the production of small-scale miners. In particular, this makes the small-scale miners illegal. The illegality restricts their access to different support mechanisms and made all their activities unregulated. They operate beyond government supervision and thus do not strive to follow health and safety regulations or meet environmental standards. Nor do they receive any formal support. They do not pay royalties to the government or taxes on profits.

Illegality extends to the marketing of gold. Intensifying the problem are the relatively high standards set by the BSP and the remote distance to the gold buying centers. Here there are clearly some disadvantages. These force the miners to sell their gold to independent gold buyers and jewellers at a lower price. The lack of formal protection increases the risk that the miners will be exploited by intermediaries or traders, and they will rarely get fair prices. In determining the price of gold, the miners merely rely on the information supplied by local gold dealers, who monitor the price of gold. In the formal markets, gold is bought at $\$ 43.00$ or approximately Php 2,000.00 per gram, pegged at the price offered by BSP. Whereas, in the informal markets of the barangays, gold is bought at Php 1200.00-1300.00 per gram. In the barangays almost all of the ASGM production is believed to be diverted into the black market.

\subsubsection{Formalization Issues}

Another important dimension relates to the informal access and absence of legal rights over mineral resources. In Cagayan de Oro City, small-scale miners operate informally to avoid regulation and participation in the formal sector. Registering their activities is regarded as a tortuous and expensive process - costly in both time and money and offering limited advantages. Generally, small-scale miners lack the expertise, financial capacity and the foresight to undertake formalization singlehandedly. If this process is to be carried out effectively, a great deal of government support will be required. For the most part, the government agency charged with regulating this area suffers from the same shortcomings as the miners. The regulatory agency lack capacity in its enforcement. This is partly a consequence of the weak decentralization process. There are also multiple agencies involved in the formalization process. Usually, conflicts arise between the regulatory agency and the local government units involved. The formalization process becomes bureaucratic and lead to excessive and differentiated costs. All these make the goal of formalization complicated and difficult.

In addition, Cagayan de Oro City is not recognized as a mining area. The SSGM activities along the Iponan River in Cagayan de Oro were not documented officially or recognized as a sector. According to a government official from the Mines and Geosciences Bureau of Region 10, the sector is too small and the contribution quite insignificant. This makes all SSGM activities in the city illegal and banned. In many cases, the government choose not to recognize their activities. Regulatory agencies also have this carefree attitude and tolerant of the SSGM activities believing that exhaustion of the available gold deposits is in the city is short-term. Raids in the mining communities are occasionally done but the regulatory agency is incapacitated to adequately stifle the mining activities given only a handful of staff to monitor and regulate the activities. According to a government official, the difficulties are in part due to the terrain of the remote areas and the limited budget. Clearly, it is not possible for the agency to monitor, let alone provide regulatory support to such a relatively bigger number of miners.

Nonetheless, a number of miners consider this a real threat especially the unannounced visits by the authorities (DENR with military assistance), which often disrupt the mining activities. According to the FGD participants, gas pumps, hoses and other mining implements have been damaged every time authorities visit the barangays. There were even incidents when raid and seizure of mining implements were conducted with the aid of helicopters. 


\subsection{Social Effects of Mining in the City}

\subsubsection{Child Labor}

The survey and FGD respondents admit children's involvement in mining adversely affects their school attendance. However, the respondents do not consider it as child labor but voluntarily assistance to their parents who usually determine their income share. According to the household survey interviewees, teenagers around 14-17 years old are already full-time miners. They are attracted to the activity because they earn higher income than most other activities in the community and eliminate the need to attend school. In addition, children as young as 5 years old are already active in panning gold along the river banks.

The results reveal relatively high incidence of truancy in the barangay. On the one hand, school-children prefer to pan gold in the rivers. On the other hand, parents fail to supervise their child's schooling as they themselves are always on the hunt for gold. At one point, an elementary principal in one of the barangays, threatened to close the school and stop offering basic education for lack of students attending the classes in almost all grade level. Also, the teachers allegedly report to school thrice a week only. Recently however, the officials in some of the barangays have already placed barangay "tanods" or community security personnels to man the school grounds to alleviate this problem.

Lack of better opportunities tends to push the minors to be involved in different activities related to mining. The largest group is made up of children aged between 14 and 17 years, the number of children who did not reach high school. Faced with limited chances of attending secondary education and vocational training, working in the mines may be the only available option.

The problem of child labor is closely connected to the problem with out-of-school-youth which could lead to other concerns as drugs and crime. This needs immediate attention as has been recognized by some barangays.

\subsubsection{Community Health and Safety}

Common illnesses experienced by the households of the barangays are fever, cough and colds. Data from the survey show that males were more prone to illnesses such as headache, muscle and body pains and pulmonary problems considered as mining related health problems as cited by FGD and survey respondents. Some respondents also claimed that mining had affected their sense of hearing due to the constant carrying of heavy loads of sand and gravel. Injuries and occasional death due to accidents and collapses of mine walls or pits have also occurred. Since mining activities are unregulated, many if not all operate outside of health and safety legislation or enforcement. Protective equipment may be cost-prohibitive for ASGM miners. Even where miners use mechanized equipment and techniques, supplementary safety measures are commonly overlooked.

Skin discoloration was observed to be common among male and female respondents. This may be attributed to the use of mercury and other such chemicals in the extraction of gold.

Another concern is the high incidence of filariasis in the barangays. This can be attributed to the prevalence of abandoned pits that have become catchment of stagnant water where the disease carrying mosquitoes thrive. Filariasis are parasites transmitted to humans through the bite of an infected mosquito and develop into adult worms in the lymphatic vessels, causing severe damage and swelling (lymphoedema). It can be painful and result to disfiguring and swelling of the legs and genital organs (WHO, 2011). As of the latest data for 2011, the Cagayan de Oro City Health Office (CHO) recorded a total of 48,756 residents in the city many of which are found in the hinterland barangays were treated for filariasis. Such barangays included Pagalungan, Tagpangi, Taglimao, Tubura, Pigsag-an, Tumpagon, Canitoan, and Pagatpat.

\subsubsection{Environmental Impacts}

The way gold mining activities are conducted and the pattern in which hydraulic mining are organized in the barangays have great implications for the people and the physical surroundings. In most cases, land degradation as well as deforestation and damage to the river are the normal and natural consequences. Other major environmental impacts caused by mining activities include diversion and pollution of rivers, water siltation, soil erosion, landscape degradation, and destruction of aquatic life habitat.

On one occasion, the researchers of this study have witnessed how a major portion of the river in the upstream barangay was diverted and dried due to a "strike". A "strike" is a situation that involves proliferation of mining groups in a given area, usually 30 to 50 groups, caused by a major discovery of big chunks of gold nugget. The discovery would 
entail more prospectors in the area where gold was found. The more prospectors in the area would ultimately lead to more physical disturbances on the river system and the nearby environs.

Based on actual observation from the data gathered by the Civil Engineering Department of Xavier University in 2010 at the different barangays along the Iponan River, sediment discharge rate was estimated at 4.2 cubic meters per second. This is about 362,880 cubic meters per day. The quantity of water discharge is at its low due to dry season. During rainy season, this quantity doubles. Regardless of the time of the year, the color of the river remains brown orange due to the dissolved and suspended solids carried by the river which ultimately deposited at the Macajalar Bay. In a year, the amount of silts deposited in the Macajalar bay is estimated to be at 420 Metric tons.

Other concerns regarding damage to the environment is related to technology used in the recovery of the minerals from the ore, especially the use of toxic mercury, or substitutes for mercury, and how the products and waste products of mines are handled. A key informant revealed that hydraulic mining operators are using mercury to separate gold from the soil.

There are many reasons why mercury use is widespread in SSGM. One of the principal reasons cited by miners is that mercury is the fastest way to extract gold. Another reason mentioned is that mercury is easily accessible and cheap. They can either buy mercury at local stores or source it out from gold dealers. Apparently, the input cost for mercury is minuscule considering that it costs only P4 to P10 per gram while gold prices can be as high as P1,300 a gram. Other reasons cited are lack of awareness of the risks of mercury use and lack of information on alternatives.

The weak enforcement of small-scale mining and other related laws and culture of tolerance and hands-off policy by both the national and local governments have rendered the problems in regulating small-scale mining. Enforcement of other environmental laws for air and water pollution, protected areas, wildlife, toxic, hazardous and solid waste are also commonly violated in most mining sites resulting to environmental problems.

\section{Conclusions}

The political ecology of the SSGM sector in the city is plagued with institutional problems and challenges. These include weak legislation, complex policies and poor implementation and sometimes government marginalization. The major problems on the livelihood of people in the barangays resulted from the inadequacy of agricultural activities and the limited job opportunities that perpetuates subsistence living of the people. As a result, small-scale mining became critically important in the barangays providing temporary or full-time work and offering potentially the only source of income.

Failure of the government to recognize the SSGM as a viable sector impedes the implementation of the policies relevant to it. Complex regulations and fragmented government institutions discourage small scale miners from seeking formalization of their activities. This has resulted to the illegal status of SSGM. More often, the widespread lack of regulation on small-scale mining means the sector do not get the much needed support for efficiency of production, fair market prices as well as protection. This has also resulted to a host of social problems that impact directly the people within the mining and the downstream communities.

\section{Acknowledgement}

The research was funded under the Mindanao Research Grant of the Kinaadman Research Center, Xavier UniversityAteneo de Cagayan.

\section{References}

Aubynn, A., Barning, K. and Dorgbetor, B. (Ed.).(2004). Goldfields Ghana Ltd

Corporate Social Responsibility. Proceedings of the National Mining Conference on Mining, the Environment and Sustainable Development. Western University College of KNUST, Tarkwa. [Online] Available: http://www.ddiglobal.org/login/Upload/Strats\% 20for\%20Sustainable\%20Dev\%20of\%20the\%20small-scale\%20mining\%20industry-Ghana.pdf

Benjaminsen, T. A. and C. Lund. (2002). Formalization and Informalization of Land and Water Rights in Africa: An Introduction, European Journal of Development Research 14(2): 1-10. [Online] Available: http://www.palgravejournals.com/ejdr/journal/ v14/n2/abs/ejdr200216a.html

Blaikie, P. (1995). Changing Environments or Changing Views? A Political Ecology for Developing Countries. Geography. Vol. 80 (3): $203-214$.

Bryant, R. and Bailey S. (1997). Third World Political Ecology. London: Routledge.

Bryceson, D. F. (2002). The Scramble in Africa: Reorienting Rural Livelihoods, World Development 30(5): 725-39. [Online] Available: 
http://www.sciencedirect.com/science/article/pii/S0305750X02000062

Carson, M., Cottrell, S., Dickman, J., Gummerson, E., Lee, T., Miao, Y.,

Teranishi, N., Tully, C., Uregian, C., 2005. Managing Mineral Resources Through Public-Private Partnerships: Mitigating Conflict in Ghanaian Gold Mining. Woodrow Wilson School of Public and International Affairs, Princeton, NJ. [Online] Available: https://www.princeton.edu/bobst/docs/WWS591c_Final_ReportMinerals_PDF.pdf

De Boeck, F. (1999). 'Domesticating Diamonds and Dollars: Identity,

Expenditure and Sharing in Southwestern Zaire (1984-1997). In B. Meyer and P. Geschiere (eds) Globalization and Identity: Dialectics of Flow and Closure, pp. 177-210. Oxford: Blackwell Publishers.

DFID. (2000). Sustainable Livelihoods Guidance Sheets. Department for International Development. [Online] Available: http://www. livelihoods.org/info/info guidancesheets.html

Duffy, R. (2005). Global Environmental Governance and the Challenge of Shadow States: The Impact of Illicit Sapphire Mining in Madagascar, Development and Change 36(5): 824-43. [Online] Available: http://www.ddiglobal.org/login/resources/ criminalisation-and-the-politics-of-governance.pdf

Drechsler, B. (2001). Chapter 4 - Tanzania and Chapter 6 - Zambia, MMSD-SA: Research Topic 1, Small-scale Mining and Sustainable Development in South Africa. [Online] Available: http://commdev.org/files/1798_file_asm_southern_africa.pdf

Espinosa Bula, D. (2000). Legalizing Small Coal Mines in Colombia, CEPMLP

Paper CP2/2000, Centre for Energy, Petroleum and Mineral Law and Policy, Dundee University: Dundee. [Online] Available: http://www. dundee.ac.uk/cepmlp/gateway/index. php?news $=28345$

Heemskerk, M. (2001). Maroon Gold Miners and Mining Risks in the Suriname Amazon, Cultural Survival Quarterly 25(1): 25-9.

Hentschel, T., Hruschka, F. and Priester,M. (2003). Artisanal and Small-Scale Mining: Challenges and Opportunities. Russell Press Ltd, Nottingham, UK.

Hilson, G. (2002). Land Use Competition in Developing Countries: Profiling the Struggles of Ghana's Galamsey Miners, Minerals and Energy, 17:3 pp 2-14. [Online] Available: https://www.google.com/\#q=Land+Use+Competition+in+Developing+Countries:+ Profiling+the+Struggles++of+ Ghana\%E2\%80\%99s+Galamsey+miners\&safe=off

Hilson, G. and C. Potter. (2003). Why is Illegal Gold Mining Activity so Ubiquitous in Rural Ghana?, African Development Review 15(2/3): 237-67. [Online] Available: http://econpapers.repec.org/article/adbadbadr/854.htm

Hinton, J. (2006). Communities and Small Scale Mining: An Integrated Review for Development Planning, Report to the World Bank. [Online] Available: http://www.globalmercuryproject.org/documents/non_country\%20specific/Communities\%20and\%20ASM\% 20(Hinton,\%202006\%20second\%20draft).pdf

IDS. (2012). Vulnerability and Poverty Reduction. Institute of Development Studies, UK. [Online] Available: www.ids.ac.uk.

ILO. (2003). Facts on Small-Scale Mining, Sustainable Development at Work, World Summit on Sustainable Development. In Livelihoods and Policy in the Artisanal and Small-Scale Mining Sector - An Overview. Centre for Development Studies University of Wales Swansea, November 2004. [Online] Available: http://r4d.dfid.gov.uk/pdf/outputs/C391.pdf

Jones, J. Y.(2001). The Socio-Economic and Environmental Impacts of Mining Reforms. [Online] Available: http://www.solidaritetshuset. org/saprap.htmo.

Labonne, B. And Gilman, J. (1999). Towards Building Sustainable Livelihoods in the Artisanal Mining Communities. Paper presented at the Tripartite Meeting on Social and Labour Issues in Small-scale Mines, ILO, Geneva. [Online] Available: http://www. naturalresources.org/minerals/development/docs/pdfs/ssminingbl.pdf/

Landell-Mills, N. and Porras. I. T. (2002). Silver Bullet or Fools' Gold: A Global Review of Markets for Forest Environmental Services and Their Impacts on the Poor. London: International Institute for Environment and Development. [Online] Available: http://www.undp. org.culeventos/aprotegidas/ES_Silv_Bullet_Fool\%27sGold.pdf

MMSD. (2002). Final Report: Artisanal and Small-scale Mining. Mining Minerals and Sustainable Development Project. London: International Institute for Environment and Development. [Online] Available: http://www.iied.org/mmsd-final-report\#eng

Republic Act No. 386, The Civil Code of the Philippines, June 18, 1949.

Republic Act (RA) 7076, People's Small-Scale Mining Act of 1991.

The National Strategic Plan for the Phaseout of Mercury in the Artisanal and Small-scale Gold Mining in the Philippines. 2011.

Tripp, A. M. (1997). Changing the Rules: The Politics of Liberalization and the Urban Informal Economy in Tanzania. Berkeley, CA: University of California Press.

Tschakert, P.and Singha, K. (2006). Research on Small-Scale Gold Mining in Ghana. Pennsylvania State University: Department of Geography. [Online] Available: http://www.geog.psu.edu/news/petra_ghana.html

Wisner, B. (2004). At Risk: Natural Hazards, People's Vulnerability and Disasters, Routledge, London.

World Health Organization (WHO). (2011). Health Topics: Filariasis. [Online] Available: http://www.who.int/topics/filariasis/en/ 